\title{
PERANCANGAN PENELITIAN ENTRI DATABASE ARSIP IMB DAN IPPT DI DINAS PENATAAN RUANG KOTA B
}

\author{
Rita Komalasari,S.Si.,M.Kom \\ Dosen Prodi Manajemen Informatika \\ Politeknik LP3I Bandung \\ Email: ritakomalasari123456@gmail.com
}

\begin{abstract}
Abstrak: Dinas Penataan Ruang melalui Seksi Dokumentasi dan Evaluasi Tata Ruang dan Bangunan pada Bidang pengawasan dan pengendalian Pemanfaatan Ruang melaksanakan Pekerjaan Pengadaan Jasa Konsultansi Penelitian Entri Database berupa kegiatan konversi arsip fisik menjadi arsip digital yang dilanjutkan dengan entri data, IPPT dan IMB beserta kelengkapan teknis dan administrasi perijinan lainnya sebanyak \pm 15.000 arsip/dokumen untuk tahun 2007, 2008, dan arsip IPPT/IMB yang pada saat ini disimpan di Dinas Perpustakaan dan Kearsipan yang kondisi fisiknya mulai mengalami kerusakan dan perlu diselamatkan, ke dalam sistem aplikasi database Berbasis Web yang sudah dimiliki oleh Dinas penataan Ruang
\end{abstract}

Kata Kunci: Arsip, Database, IMB, IPPT

\section{Pendahuluan \\ 1.1 Latar Belakang Masalah}

Arsip merupakan salah satu sumber informasi yang memiliki peranan potensial dan tidak mungkin dapat dihapus dalam menunjang kelancaran kegiatan administrasi sehari-hari di segala bidang kegiatan. Arsip mempunyai peranan sebagai pusat kegiatan, sumber informasi dan sebagai alat pengawas yang sangat diperlukan dalam setiap organisasi dalam melakukan perencanaan, penganalisaan, pengembangan, perumusan, kebijaksanaan, pengambilan keputusan, penelitian dan pengendalian secara tepat.

Mengingat pentingnya arsip tersebut di atas maka perlu adanya manajemen kearsipan atau sistem pengelolaan yang sistematis, efektif dan efisien. Hal ini untuk memudahkan dalam mencari, mengatur, memanfaatkan dan menginventarisir masing- masing jenis kearsipannya. Adapun tujuannya guna menjamin keselamatan arsip agar suatu waktu diperlukan masih dapat disediakan dengan cepat, tepat dan akurat.

Pertumbuhan dokumen yang dihasilkan dari proses administrasi akan menyebabkan terjadinya penumpukan dan menimbulkan permasalahan, seperti meningkatnya kebutuhan akan ruang penyimpanan dokumen, peralatan, sumber daya manusia (SDM) serta kesulitan untuk menemukan kembali arsip/dokumen yang dibutuhkan. Oleh karena itu, usaha-usaha untuk mengantisipasi permasalahan tersebut sudah waktunya untuk dipersiapkan, antara lain penataan fisik dokumen secara baik dan benar serta sesuai dengan prinsip-prinsip kearsipan.

Dengan memperhatikan amanat Undang Undang Nomor 43 Tahun 2009 tentang kearsipan dan semakin meningkatnya permintaan informasi secara cepat, tepat, dan akurat serta dalam rangka menjalankan tugas pokok dan fungsi maka diperlukan pengelolaan informasi secara efektif dan efisien. Untuk memenuhi maksud tersebut di atas, Dinas Penataan Ruang melalui Seksi Dokumentasi dan Evaluasi Tata Ruang 
dan Bangunan pada Bidang pengawasan dan pengendalian Pemanfaatan Ruang melaksanakan Pekerjaan Pengadaan Jasa Konsultansi Penelitian Entri Database berupa kegiatan konversi arsip fisik menjadi arsip digital yang dilanjutkan dengan entri data, IPPT dan IMB beserta kelengkapan teknis dan administrasi perijinan lainnya sebanyak \pm 15.000 arsip/dokumen untuk tahun 2007, 2008, dan arsip IPPT/IMB yang pada saat ini disimpan di Dinas Perpustakaan dan Kearsipan yang kondisi fisiknya mulai mengalami kerusakan dan perlu diselamatkan, ke dalam sistem aplikasi database Berbasis Web yang sudah dimiliki oleh Dinas penataan Ruang Kota Bandung.

Sistem aplikasi dan database dokumentasi arsip ini dibuat untuk memudahkan pencarian, pencatatan, serta pelaporan data arsip secara akurat, cepat dan tepat waktu.

Tujuan dilaksanakannya kegiatan ini yaitu

Tujuan dari kegiatan ini adalah mengkonversi arsip/dokumen fisik menjadi arsip/dokumen digital dan melakukan input data IPPT dan IMB, serta kelengkapan teknis dan administrasi perijinan lainnya ke dalam sistem aplikasi database berbasis Web yang sudah dimiliki oleh Dinas Penataan Ruang

Sasaran Pekerjaan :

1. Terbentuknya dokumentasi data IPPT dan IMB beserta kelengkapan teknis dan administrasi perijinan lainnya secara digital yang berguna dan bermanfaat secara nyata terutama bagi penyelenggaraan tugas pada Seksi Dokumentasi dan Evaluasi Tata Ruang dan Bangunan di Dinas Penataan

2. Terbentuknya sarana penyimpanan arsip/dokumen IPPT dan IMB beserta kelengkapan teknis dan administrasi perijinan lainnya secara digital yang memiliki kelebihan antara lain menghemat ruang, sebagai back up/cadangan data, meminimalkan resiko kerusakan dan kehilangan fisik arsip, serta pengamanan arsip dari pihak-pihak yang tidak bertanggung jawab.

3. Terbentuknya data dokumentasi digital arsip/dokumen IPPT dan IMB beserta kelengkapan teknis dan administrasi perijinan lainnya yang terstruktur dalam bentuk databas e dalam rangka penatakelolaan data arsip yang lebih baik.

\section{Tinjauan Pustaka}

\subsection{Pengertian Arsip}

Dalam setiap kegiatan instansi, untuk mencapai suatu tujuan yang telah ditetapkan dalam perencanaan dibutuhkan data dan informasi. Salah satu sumber data adalah arsip. Menurut Undang-Undang No. 7 tahun 1971 tentang ketentuan-ketentuan pokok kearsipan, Bab I pasal 1 menegaskan bahwa yang dimaksudkan dengan arsip adalah :

1. naskah-naskah yang dibuat dan diterima oleh Lembaga-lembaga Negara dan Badanbadan pemerintahan dalam bentuk corak apapun baik dalam keadaan tunggal maupun berkelompok, dalam rangka pelaksanaan kegiatan pemerintahan;

2. naskah-naskah yang dibuat dan diterima oleh Badan-badan swasta dan/atau perorangan, dalam bentuk corak apapun, baik dalam keadaan tunggal maupun berkelompok, dalam rangka pelaksanaan kehidupan kebangsaan.

Mengingat pentingnya arsip tersebut di atas maka perlu adanya manajemen kearsipan atau sistem pengelolaan yang sistematis, efektif dan efisien. Hal ini untuk memudahkan dalam mencari, mengatur, memanfaatkan dan menginventarisir masing- masing jenis 
kearsipannya. Adapun tujuannya guna menjamin keselamatan arsip agar suatu waktu diperlukan masih dapat disediakan dengan cepat, tepat dan akurat.

Pertumbuhan dokumen yang dihasilkan dari proses administrasi akan menyebabkan terjadinya penumpukan dan menimbulkan permasalahan, seperti meningkatnya kebutuhan akan ruang penyimpanan dokumen, peralatan, sumber daya manusia (SDM) serta kesulitan untuk menemukan kembali arsip/dokumen yang dibutuhkan. Oleh karena itu, usaha-usaha untuk mengantisipasi permasalahan tersebut sudah waktunya untuk dipersiapkan, antara lain penataan fisik dokumen secara baik dan benar serta sesuai dengan prinsip-prinsip kearsipan.

Pada era teknologi informasi saat ini, penyajian data dituntut agar dapat lebih mempermudah dalam penggunaannya. Data digital merupakan solusi yang tepat dalam mengatasi permasalahan data yang belum terorganisasi.

\section{2..2 Ruang lingkup Entri Database Arsip IMB dan IPPT}

Entri Database Arsip IMB dan IPPT ini meliputi seluruh pekerjaan mulai dari persiapan hingga penyusunan buku laporan akhir yang menjadi landasan dalam pengambilan kebijakan dibidang tertib administrasi kearsipan. Secara umum ruang lingkup pekerjaan sesuai dengan Undang Undang Nomor 43 Tahun 2009 tentang kearsipan dan semakin meningkatnya permintaan informasi secara cepat, tepat, dan akurat serta dalam rangka menjalankan tugas pokok dan fungsi maka diperlukan pengelolaan informasi secara efektif dan efisien.

Ruang lingkup dan batasan Pekerjaan Jasa Konsultansi Entry Data Base Arsip adalah sebagai berikut:

1. Konversi arsip/dokumen fisik menjadi digital, input data IPPT/IMB beserta kelengkapan teknis dan administrasi perijinan lainnya ke dalam sistem aplikasi database Berbasis Web yang sudah dimiliki oleh Dinas Penataan Ruang

a. Ijin Peruntukan Penggunaan Tanah (IPPT)

Ijin peruntukan Penggunaan Tanah (IPPT) adalah Ijin Perencanaan dan/atau rekomendasi perencanaan bagi penggunaan tanah yang didasarkan pada Rencana Tata Ruang Wilayah (RTRW), Rencana Detail Tata Ruang Kota (RDTRK) dan/atau Rencana Teknik Ruang Kota (RTRK).

Ijin Peruntukan Penggunaan Tanah terdiri dari Ijin Perencanaan dan rekomendasi Perencanaan. Ijin Perencanaan merupakan salah satu persyaratan administratif untuk memperoleh Ijin Mendirikan Bangunan.

Ijin Peruntukan Penggunaan Tanah (IPPT) sebagaimana yang dimaksud berlaku untuk jangka waktu 1 (satu) tahun terhitung sejak tanggal ditetapkannya sepanjang pemegang ijin tidak memproses permohonan ijin selanjutnya, serta dapat diperpanjang 1(satu) kali berdasarkan permohonan yang bersangkutan.

b. Izin Mendirikan Bangunan yang selanjutnya disingkat IMB adalah Keputusan Tata Usaha Negara yang diberikan kepada setiap orang yang telah memenuhi persyaratan yang ditentukan untuk membangun, memperluas, mengurangi, merawat,dan mengubah bangunan gedung dan bangun bangunan.

2. Memanfaatkan konfigurasi perangkat keras dan perangkat lunak serta infrastruktur sistem aplikasi database Arsip Berbasis Web yang sudah dimiliki oleh Dinas Penataan Ruang kepada pengguna di Bidang Pengawasan dan Pengendalian Pemanfaatan Ruang khususnya Seksi Dokumentasi dan Evaluasi Tata Ruang dan Bangunan untuk kebutuhan penyediaan dan penatakelolaan data. 
3. Pendataan IPPT dan IMB beserta kelengkapan teknis dan administrasi perijinan lainnya untuk tahun 2007, 2008, dan arsip IPPT/IMB yang pada saat ini disimpan di Dinas Perpustakaan dan Kearsipan yang kondisi fisiknya mulai mengalami kerusakan dan perlu diselamatkan, dengan total jumlah arsip sebanyak \pm 15.000 dokumen.

\subsection{Kajian Kebijakan Penelitian Entri Database Arsip IMB dan IPPT}

Peraturan perundang-undangan yang terkait dengan Penelitian Entri Database Arsip IMB dan IPPT sebagai berikut:

1. Undang-undang Republik Indonesia No. 7 Tahun 1971 tentang ketentuan-ketentuan pokok kearsipan sebagai pengganti Peraturan Presiden Nomor 19 tahun 1961 tentang pokok- pokok kearsipan nasional.

2. Undang - undang Republik Indonesia No. 8 Tahun 1999 tentang Dokumen Perusahaan.

3. Undang - undang Republik Indonesia No. 14 tahun 2008 tentang Keterbukaan Informasi Publik.

4. Undang - undang Republik Indonesia Nomor 43 Tahun 2009 tentang Kearsipan.

5. Undang - undang Republik Indonesia Nomor 28 Tahun 2009 tentang Bangunan Gedung.

6. Undang-undang Nomor 23 Tahun 2014 tentang Pemerintahan Daerah.

7. Peraturan Pemerintah No. 36 tahun 2005 tentang pelaksanaan Undang- Undang No. 28 Tahun 2009 Tentang Bangunan Gedung.

8. Peraturan Presiden Nomor 70 Tahun 2012 tentang pelaksanaan Undang-undang nomor 43 Tahun 2009 Tentang Kearsipan.

9. Untuk mendukung bagi pelaksanaannya Undang-undang Nomor 7 Tahun 1971, maka dikeluarkan Keputusan Presiden Nomor 26 Tahun 1974 tentang Arsip Nasional Republik Indonesia.

10. Keputusan Presiden Nomor 105 Tahun 2005 Tentang Pengelolaan Arsip Statis.

11. Keputusan Menteri Dalam Negeri RI No. 100 tahun 1991 Tentang Jadwal Retensi Arsip.

12. Peraturan Menteri Dalam Negeri RI Nomor 2005 Tentang Tata Kearsipan Di Lingkungan Depdagri.

13. Peraturan Daerah Kota Bandung Nomor 5 Tahun 2010 Tentang Bangunan Gedung.

14. Peraturan Daerah Kota Bandung Nomor 12 Tahun 2011 Tentang Penyelenggaraan Retribusi Ijin Mendirikan Bangunan dan Retribusi Biaya Penggantian Cetak Peta.

15. Peraturan Daerah Kota Bandung Nomor 7 Tahun 2013 Tentang Penyediaan Penyerahan dan Pengelolaan Prasarana, sarana dan Utilitas Perumahan dan kawasan Pemukiman.

16. Peraturan Daerah Kota Bandung Nomor 18 Tahun 2011 Tentang Rencana Tata Ruang Wilayah Kota Bandung Tahun 2011 - 2031.

17. Peraturan Walikota Bandung Nomor 01 Tahun 2017 tentang Pelaksanaan Anggaran Pendapatan dan Belanja Daerah.; 


\subsection{Metodologi Penelitian Entri Database Arsip IMB dan IPPT}

SIG adalah sistem yang berbasiskan komputer yang digunakan untuk menyimpan Metodologi yang digunakan dalam pekerjaan Jasa Konsultansi Entry Data Base Arsip menggunakan tahapan - tahapan analisa kebutuhan dan pengembangan sistem sebagai berikut :

1. Persiapan dan analisis kebutuhan

Melakukan studi terhadap perundangan dan literatur yang berhubungan dengan pekerjaan Jasa Konsultansi Entry Data Base Arsip :

a. Peraturan perundangan (UU, PP, Permen, Perda)

b. Teori pendukung

c. Hasil studi terkait

d. Survei wawancara

\section{Identifikasi Kebutuhan Terhadap Data IMB dan data terkait.}

Sebelum proses pencarian data IMB dilakukan, maka diperlukan identifikasi kebutuhan mengapa data tersebut diperlukan dan data apa saja yang terkait dengan proses penerbitan IMB. Kebutuhan terhadap data IMB dari tujuan yang ingin dicapai yaitu :

a. Untuk mempermudah dan mempercepat mendapatkan data dan informasi Arsip IMB, IPPT yang ada untuk kurun waktu tahun 2007 dan 2008 sehingga dapat dilakukan penghematan waktu.

b. Mempermudah inventarisasi jenis dan kelompok Arsip IMB, IPPT.

Pembagian Wilayah :

- Bojonegara

- Karees

- Cibeunying

- Ujungberung

- Tegallega

- Gedebage

Tersusunnya data Arsip IMB, IPPT yang sistematis melalui database.

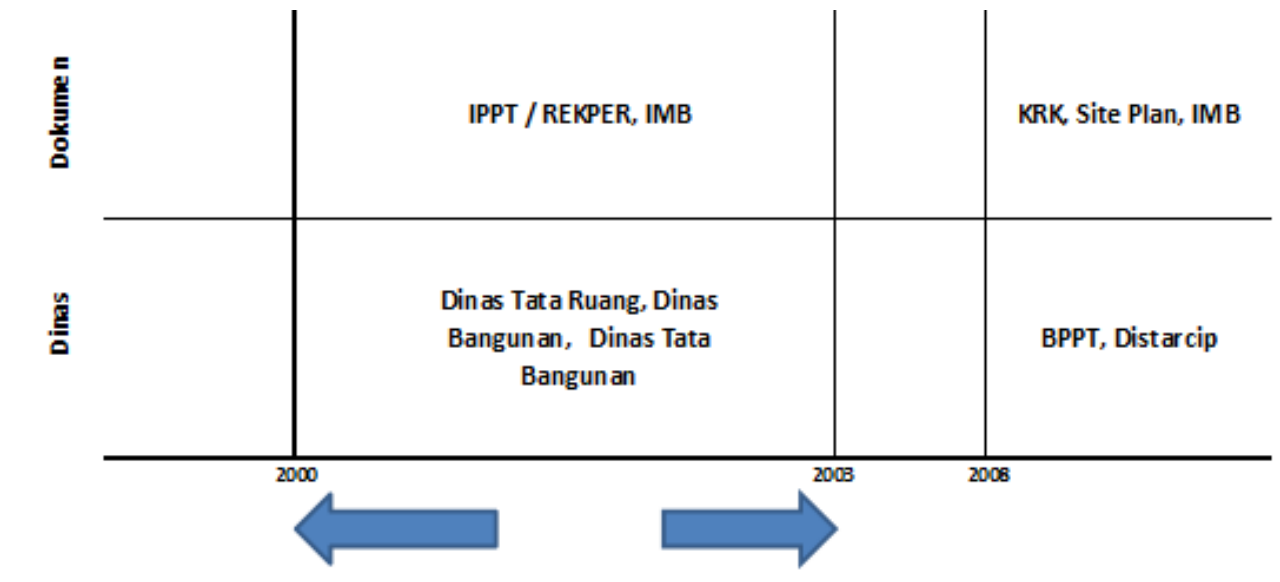

Gambar 1. Dokumen terkait pekerjaan entri database arsip 


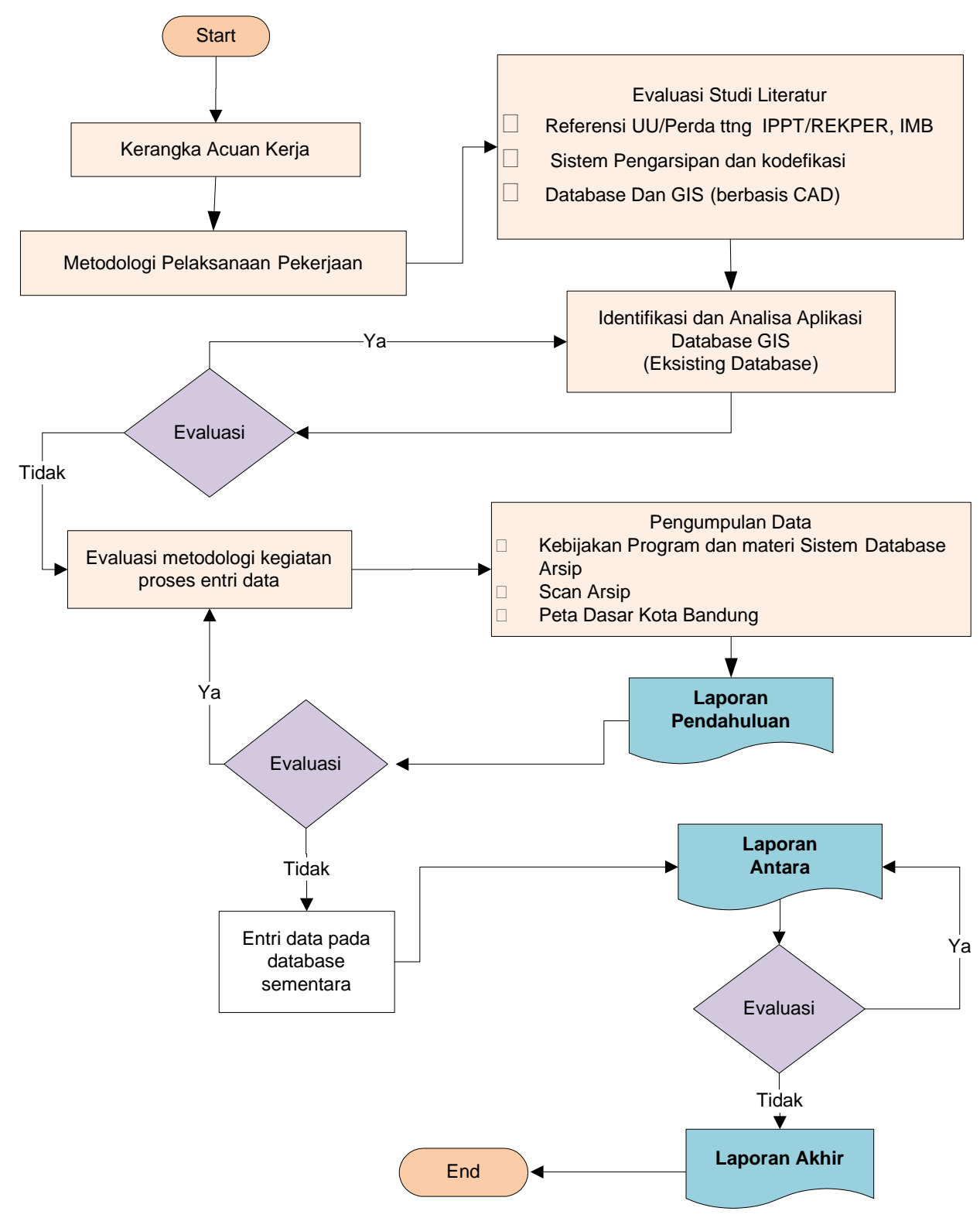

Gambar 2. Metodologi Pekerjaan Secara Keseluruhan

\section{Asumsi Perhitungan Waktu Kegiatan}

Memperhitungkan perkiraan jumlah data dokumen arsip IMB dan IPPT. Jumlah data Arsip IMB, IPPT yaitu mencapai +15.000 dokumen untuk tahun 2007, 2008 dengan asumsi) sebagai berikut :

a. Jumlah Pemohon 1 hari $=31$ dokumen perizinan/hari

b. Perbulan terdapat 22 hari kerja : 31 dokumen perizinan/hari $\times 22$ hari $=682$ dokumen perizinan/bulan

c. Pertahun terdapat 11 bulan efektif bekerja : 682 dokumen perizinan/bulan x 11 bulan $=7.500$ dokumen perizinan/tahun 
d. Jumlah data IMB, IPPT tahun 2007, 2008 : 7.500 dokumen perizinan/tahun x 2 tahun $=15.000$ dokumen

e. Jumlah Dokumen IMB, IPPT akan maksimal diasumsikan 15.000 Dokumen

2. Survey pada sistem

a. Konsep Sistem Informasi User friendly Entri data dokumentasi IMB, IPPT beserta kelengkapan teknis dan administrasi perijinan lainnya

b. Metoda dan formulir survey

3. Analisa Sistem Data Base Arsip Eksisting

Pada tahun anggaran 2014 Dinas Tata Ruang dan Cipta Karya Kota Bandung telah melaksanakan Pekerjaan Pengadaan Jasa Konsultansi Penelitian Pembuatan Database Arsip di dalam Kegiatan Monitoring Evaluasi dan Pelaporan yang menghasilkan keluaran/output berupa Aplikasi Database Berbasis Web dan Aplikasi GIS Peta Rencana Kota Bandung Berbasis CAD serta Database Dokumentasi Arsip IMB, IPPT, REKPER beserta kelengkapan teknis dan administrasi perijinan lainnya
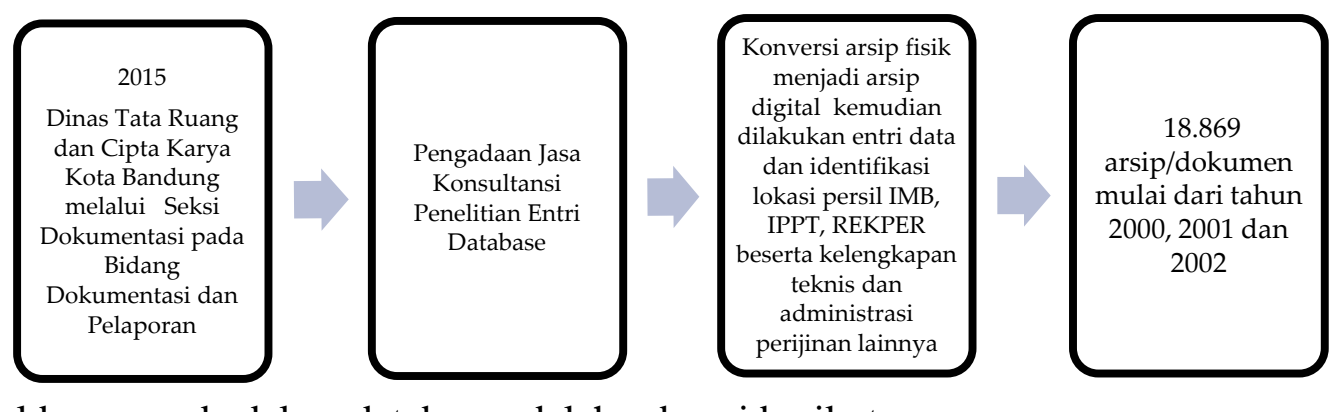

Field yang ada dalam database adalah sebagai berikut :

Stuktur Tabel IMB

\begin{tabular}{|l|l|l|}
\hline \multicolumn{1}{|c|}{ Column } & nmr_arsip_imb \\
\hline id & nmi_arsip_ippt \\
\hline norekippt & tahunregippt \\
\hline noregimb & tahunregimb \\
\hline nosimb & peruntukan \\
\hline namakelurahan & namapemohon \\
\hline idkelurahan & alamatpemohon \\
\hline namakecamatan & lokasi \\
\hline idkecamatan & luastanah \\
\hline ramawilayah & reticsetemryat \\
\hline idwilayah & penggunaar \\
\hline jenisberkas & berdidirikan \\
\hline simb untuk & far \\
\hline tgl_simb & jalan \\
\hline bln_arsip_imb & luaspersil \\
\hline luastapakimb \\
\hline
\end{tabular}

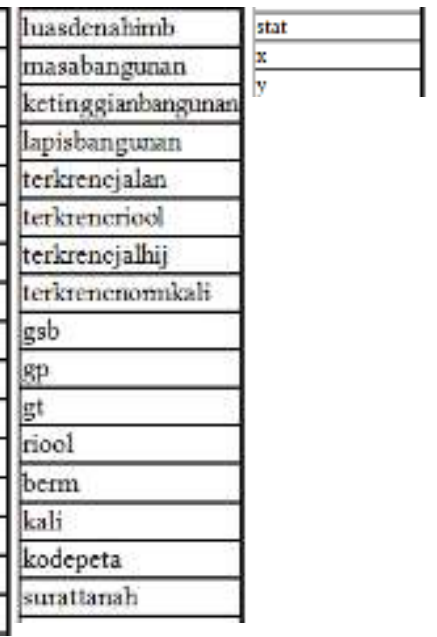

Struktur Tabel IPPT

\begin{tabular}{|l|}
\hline \multicolumn{1}{|c|}{ Column } \\
\hline Nama kelurahan \\
\hline Nama kecamatan \\
\hline Nama wilayah \\
\hline \hline Jenis berkas \\
\hline Tgl_arsip_ippt \\
\hline Nmr_arsip_ippt \\
\hline No rekippt \\
\hline Tgl rekippt \\
\hline Peruntukan \\
\hline No urut \\
\hline
\end{tabular}
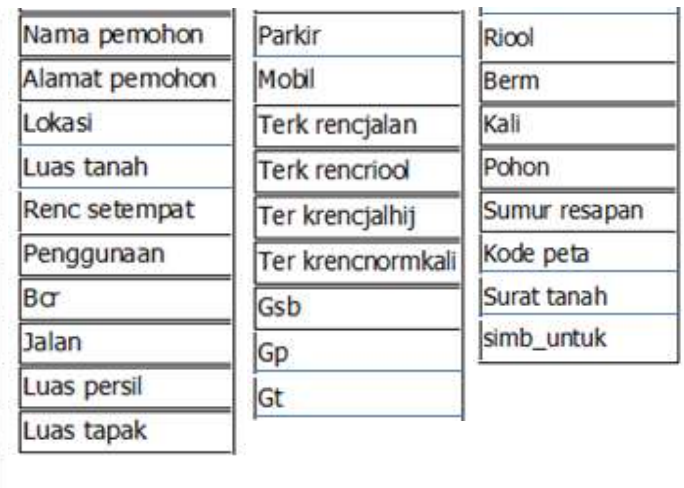
4. Analisa sistem perangkat keras dan perangkat lunak Analisis Perangkat keras, Sistem Operasi dan jaringan infrastruktur.

5. Entri Data IPPT dan IMB beserta kelengkapan teknis dan administrasi perijinan lainnya ke sistem

Setelah metode prioritas entri data IMB, REKPER ditentukan, langkah berikutnya ialah melakukan penyaringan dan pengumpulan data. Penyaringan dilakukan diperoleh data IMB, IPPT yang sesuai saja, sedang yang tidak sesuai dapat abaikan (untuk dientri kemudian).

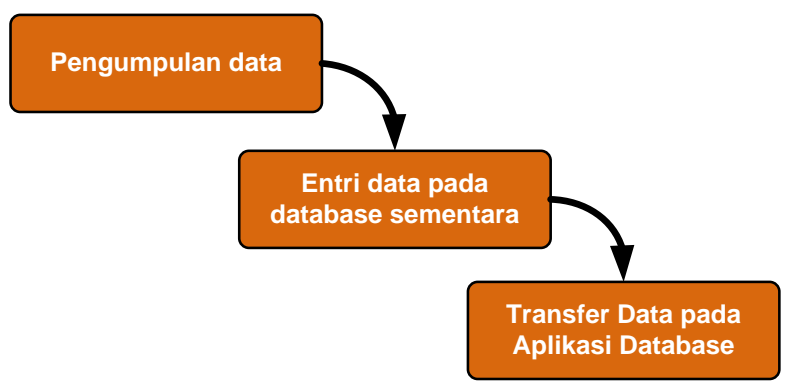

Gambar B 3. Metodologi Proses Kegiatan Entri Data

\section{Asumsi Perhitungan Waktu Pengolahan Data dan Entry Data oleh Operator Komputer :}

Asumsi perhitungan waktu kerja Pengolaha dan Operator Entry data adalah sebagai berikut :

a. Jumlah dokumen perizinan tahun $2007,2008=15.000$ dokumen perizinan

b. Jumlah tenaga pengolah/operator komputer $=20$ Orang

c. Jumlah waktu yang disediakan dalam pengolahan data $=120$ hari kerja

d. Jumlah dokumen/hari yang dapat dikerjakan selama 120 hari :

15.000 dokumen perizinan dibagi 120 hari $=15.000: 120=125$ Dokumen perijinan/hari

e. Setiap tenaga pengolah/operator komputer data dapat menyaring dan mengumpulkan data:

125 dokumen perijinan/hari : 20 tenaga /operator komputer $= \pm 7$ dokumen perijinan/hari

f. Jenis kegiatan yang akan dilaksanakan terdiri dari 3 kegiatan setiap tenaga pengolah/operator computer terdiri dari 1). Entri data 2). Scan dokumen, 3). Rekam gambar

g. Kesimpulan sementara setiap tenaga pengolah /operator entry data menyelesaikan 3 tahap (Entry + Scan Dok + Rekam Gambar) x 7 dokumen $=21$ dokumen arsip/orang/hari.

Setelah proses pengumpulan dan penyaringan selesai, maka proses entry data data dapat dilaksanakan dengan jumlah tenaga operator yang sama. 
Data IPPT, IMB yang telah terkumpul perlu dievaluasi terlebih dahulu, khususnya berkaitan dengan kualitas, kesesuaian dan kecukupan data. Proses evaluasi data dapat dilakukan dengan melakukan konsultasi dengan pihak yang terkait yaitu terutama mengenai jumlah data dan jumlah Dokumen yang terhimpun dari hasil Entri.

6. Finalisasi Pekerjaan

Dilakukan proses Stock opname untuk menghitung hasil pekerjaan Jasa Konsultansi Entri Data Base Arsip sebagai pertanggungjawaban jumlah dokumen Arsip.

\section{Analisis Metode Pekerjaan}

Seluruh dasar dari pekerjaan kegiatan entri data ini senantiasa mengacu pada KAK yang sudah ditetapkan. Metodologi pekerjaan kegiatan entry data dapat dilihat pada gambar berikut :

Proses entri data kedalam database sementara secara offline, agar proses entri data dapat selesai pada waktunya.

\begin{tabular}{|c|c|c|c|c|c|c|}
\hline \multicolumn{7}{|c|}{ ] imb.geseses } \\
\hline id & norekippt & tahunregippt & naregimb & nosimb & - tahunregimb. & tgl_simb \\
\hline & 508 503.640/1158/VV/DTK/2000 & 2000 & $503.645 / 8 / 1597 / \mathrm{DB} / \mathrm{V} 1 / 2000$ & 503.645.8/51-1668-Di5BANG/2000 & 2000 & $11 / 08 / 20$ \\
\hline & $410503.540 / 849 / \mathrm{VI} / \mathrm{OTK} / 2000$ & 2000 & S03.648.1/1411/DISBANG-VI-2000 & S03.648.1/51-1447-DISEANG/2000 & 2000 & $18 / 07 / 20$ \\
\hline & $411503.640 / 950 / \mathrm{VII} / \mathrm{OTK} / 2000$ & 2000 & S03.648.1/1464-DISBANG-VI-2000 & 503.648. $1 / 51$ 14770-DisBANG/2000 & 2000 & $20 / 07 / 20$ \\
\hline & $412503.640 / 527 / \mathrm{V} / \mathrm{OTK} / 2000$ & 2000 & 503.648.1/1518/DisBANG.V1/2000 & 503.648.1/51.1558-DISBANG/2000 & 2000 & $28 / 07 / 20$ \\
\hline & 413 503.640/10/(V/DTK/1996 & 1996 & $503.648 .1 / 1354 / 0 \mathrm{~B} \cdot \mathrm{Vl} 1.2000$ & S03.648.1/51 -1402-DISBANG/00 & 2000 & $12 / 07 / 20$ \\
\hline & $414503.640 / 278 / \mathrm{V} / \mathrm{DTK} / 2000$ & 2000 & $503.648 .1 / 1349 / \mathrm{DB} / \mathrm{V} \mathrm{V} / 2000$ & 503.648.1/51-1429-DISBANG/2000 & 2000 & $15 / 07 / 20$ \\
\hline & 415 503.640/847/VII/OTK/2000 & 2000 & S03.648.1/14334-D15BANG-Vt-2000 & S03.648.1/51-S1-1445-DISBANG/2000 & 2000 & $18 / 07 / 20$ \\
\hline & 416 503.640/1229/VWI/DTK/2000 & 2000 & $503.648 .1 / 1678 / \mathrm{DP} / \mathrm{V} \mathrm{V} / 2000$ & 503.648.1/51-1650-DisBANG/2000 & 2000 & $11 / 08 / 20$ \\
\hline & $417503.640 / 963 / \mathrm{VII} / \mathrm{DTK} / 2000$ & 2000 & 503.648.1/1472-DISEANG-VI-2000 & 503.648.1/51-1468-DISBANG/2000 & 2000 & $20 / 07 / 20$ \\
\hline & $418503.640 / 887 / \mathrm{VI1} / 2000$ & 2000 & $503.648 .1 / 1451 / D B / V 1 / 2000$ & 503.648.1/51-1553-D15BANG/2000 & 2000 & $27 / 07 / 20$ \\
\hline & $419.503 .640 / 1136 / \mathrm{Nu} / \mathrm{OTK} / 2000$ & 2000 & $503.649 .1 / 1635 / \mathrm{DB} / \mathrm{N} / 2000$ & S03.648.1/51. 1679-Dis8ANG/2000 & 2000 & $11 / 08 / 20$ \\
\hline & $420503.640 / 555 / \mathrm{VI} / \mathrm{DTK} / 2000$ & 2000 & S03.645.8/1541-DISBANG-V1/2000 & 503.645.8/S1:1616-DISBANG/2000 & 2000 & $04 / 08 / 20$ \\
\hline & $421,503.640 / 1007 / \mathrm{VII} / \mathrm{DTK} / 2000$ & 2000 & $503.648 .1 / 1522-\mathrm{DB} \cdot \mathrm{Vl}-2000$ & 503.648.1/St-1638-DISBANG/2000 & 2000 & $05 / 08 / 20$ \\
\hline & $422503.640 / 539 / \mathrm{V} / \mathrm{DTK} / 2000$ & 2000 & $503.643 .1 / 1463 / \mathrm{DB} / \mathrm{V} / 2000$ & S03.648.1/51-14887-DISBANG/2000 & 2000 & $22 / 07 / 20$ \\
\hline & $423503.600 / 851 / \mathrm{VII} / \mathrm{DTK} / 2000$ & 2000 & 503.648.1/1426-DISEANG-VI-2000 & 503.648.1/51-1466-D158ANG/2000 & 2000 & $20 / 07 / 20$ \\
\hline & $424503.640 / 852 / \mathrm{VI} / \mathrm{OTK} / 2000$ & 2000 & 503.644.2/1524-DISBANG-VI-2000 & 503.644.2/51-1577-0158ANG/2000 & 2000 & $31 / 07 / 20$ \\
\hline & A25 503.640/1006/VII/DTK/2000 & 2000 & $503.648,1 / 1521-D Q-V 1-2000$ & S03.648.1/S1-1637-DISBANG/2000 & 2000 & $05 / 08 / 20$ \\
\hline & $426503.640 / 564 / V 1 / D T K / 2000$ & 2000 & $503.648 .1 / 1519 / \mathrm{DB}-\mathrm{V} / 2000$ & 503.645.1/51-1635-DISBANG/2000 & 2000 & $05 / 08 / 20$ \\
\hline & $427503.640 / 900 / \mathrm{VI} / \mathrm{OTT} / 2000$ & 2000 & S03.648.1/14831/V1/DISBANG/2000 & 503.645.1/51-1552-0158ANG/2000 & 2000 & $27 / 07 / 20$ \\
\hline
\end{tabular}

Gambar 4. Proses entry data perwilayah 


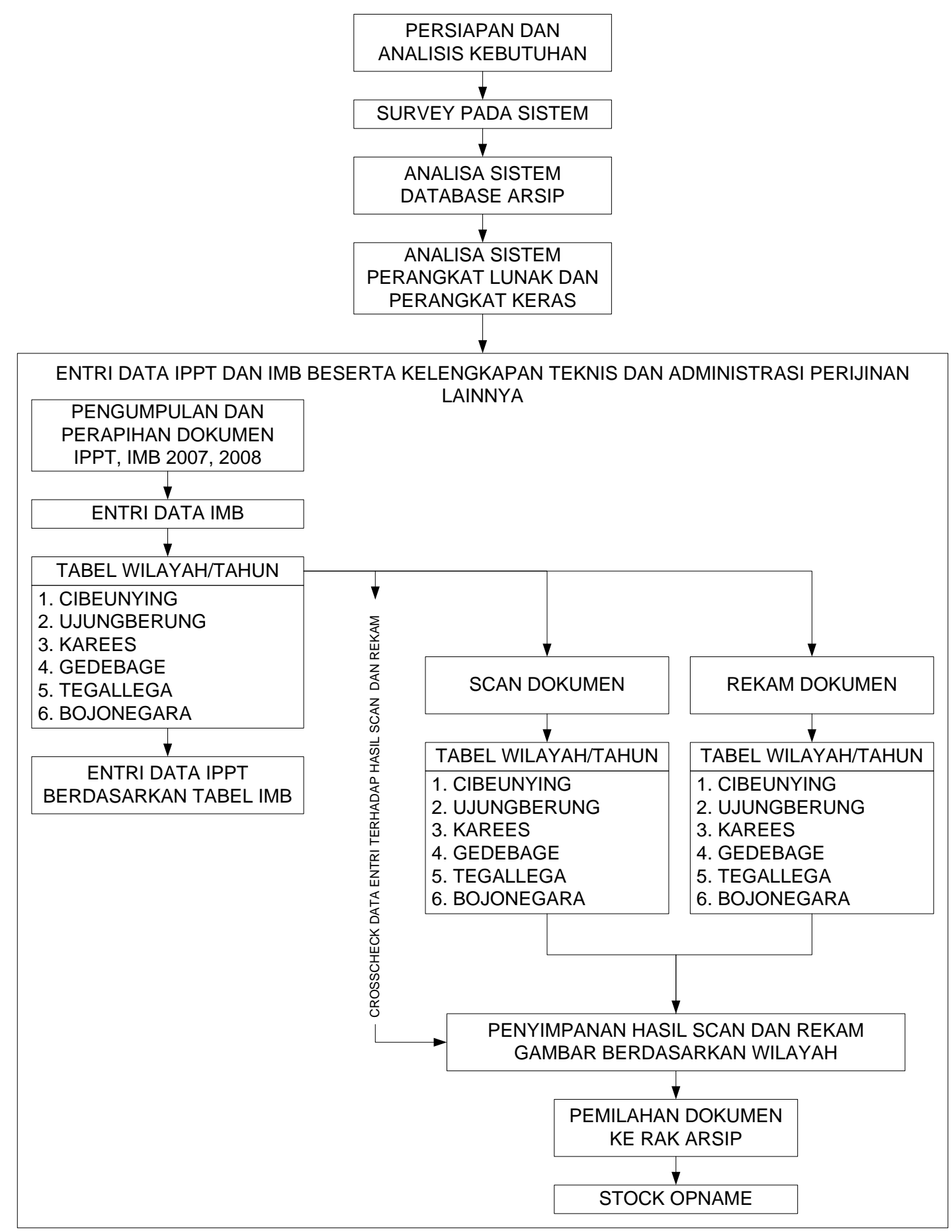

Gambar 5. Metode pekerjaan

\section{Entri data pada aplikasi Data Base Master}

Pada tahap ini dilakukan proses penggabungan data atau disebut juga dengan eksport data kedalam database master yang dimiliki oleh aplikasi database yang ada. 
1. Tampilan Data IMB

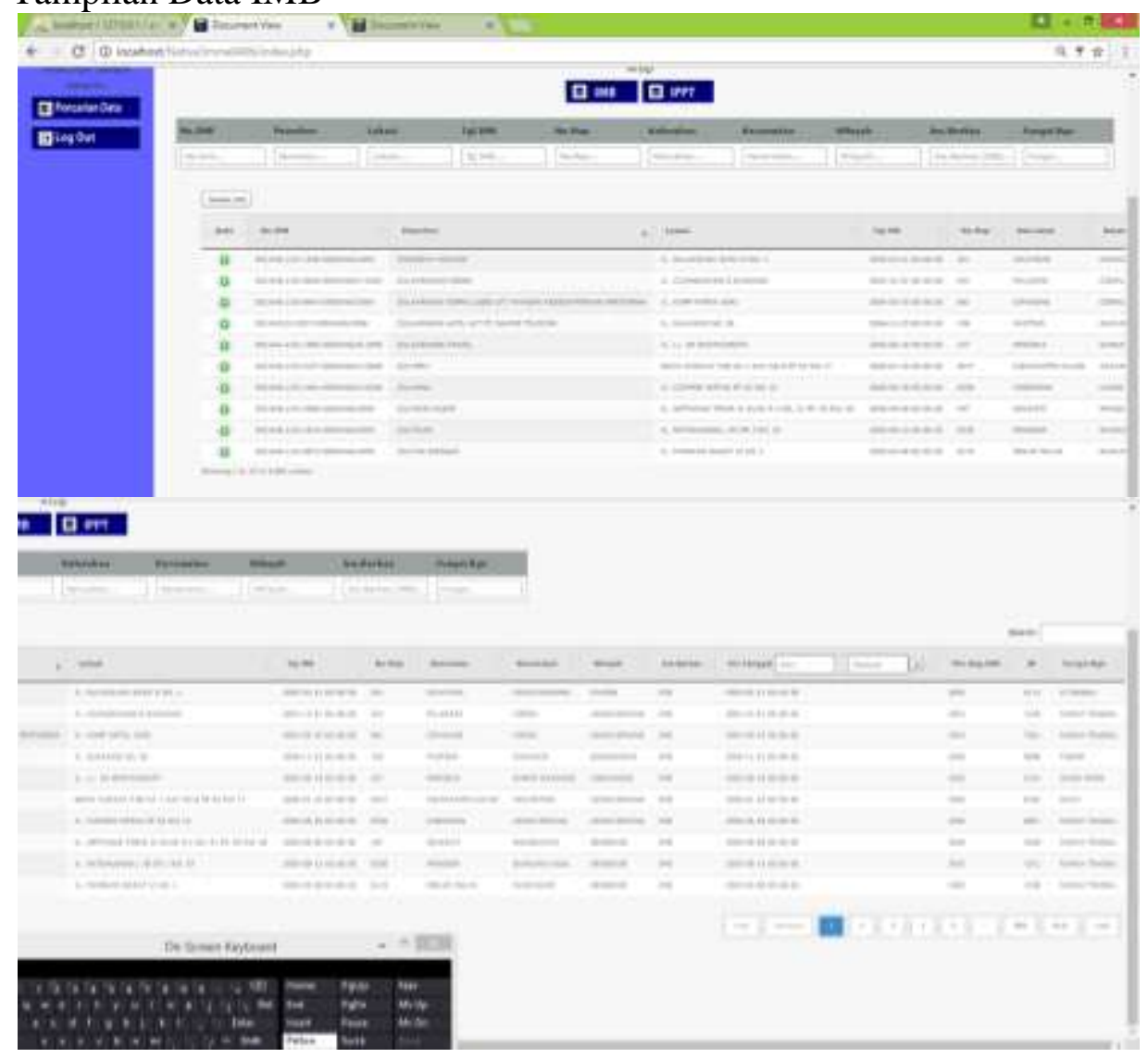

Gambar 6. Tampilan Data IMB

2. Data IMB Detail

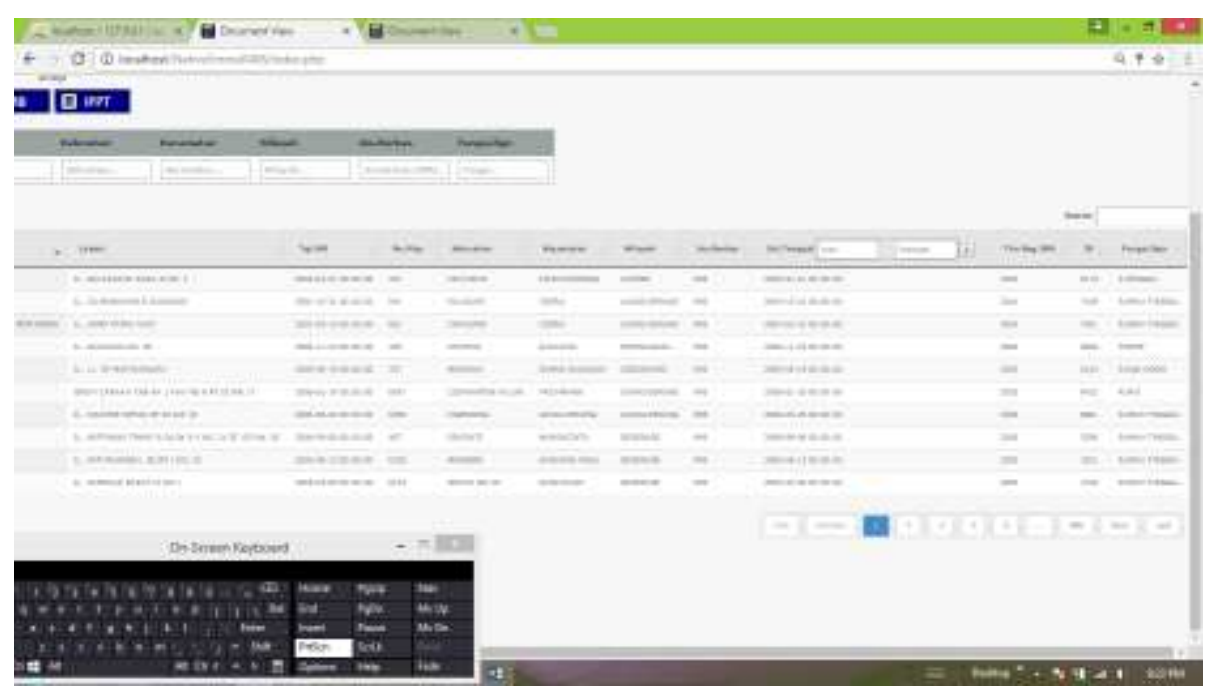




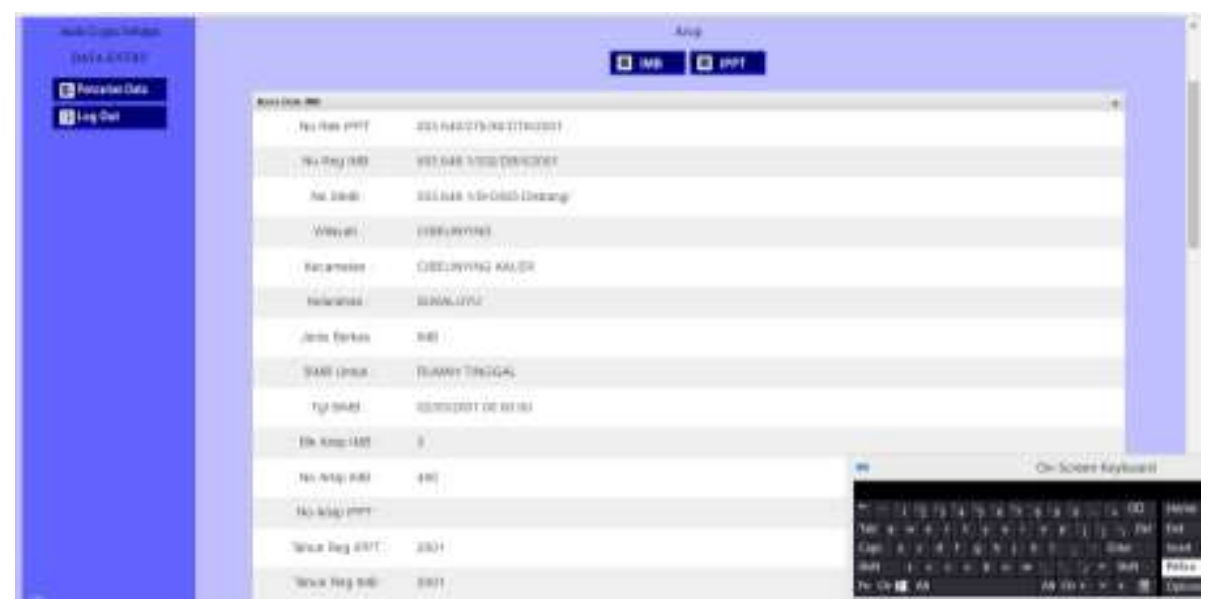

Gambar 7. Tampilan Data IMB detail

3. Tampilan input Data

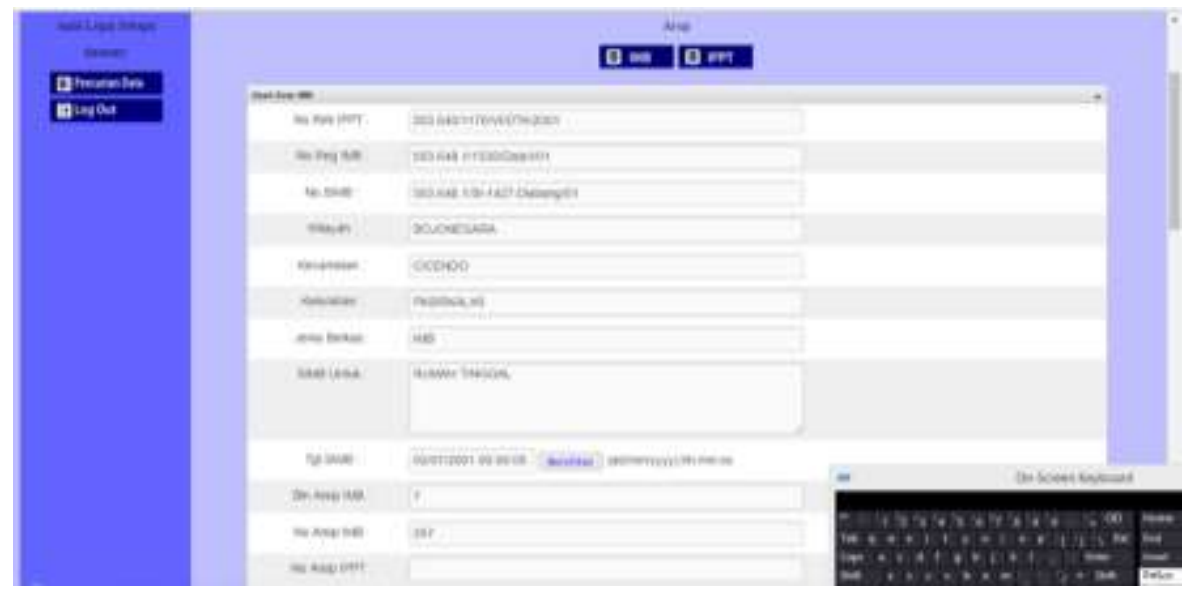

Gambar 8. Form tampilan input data

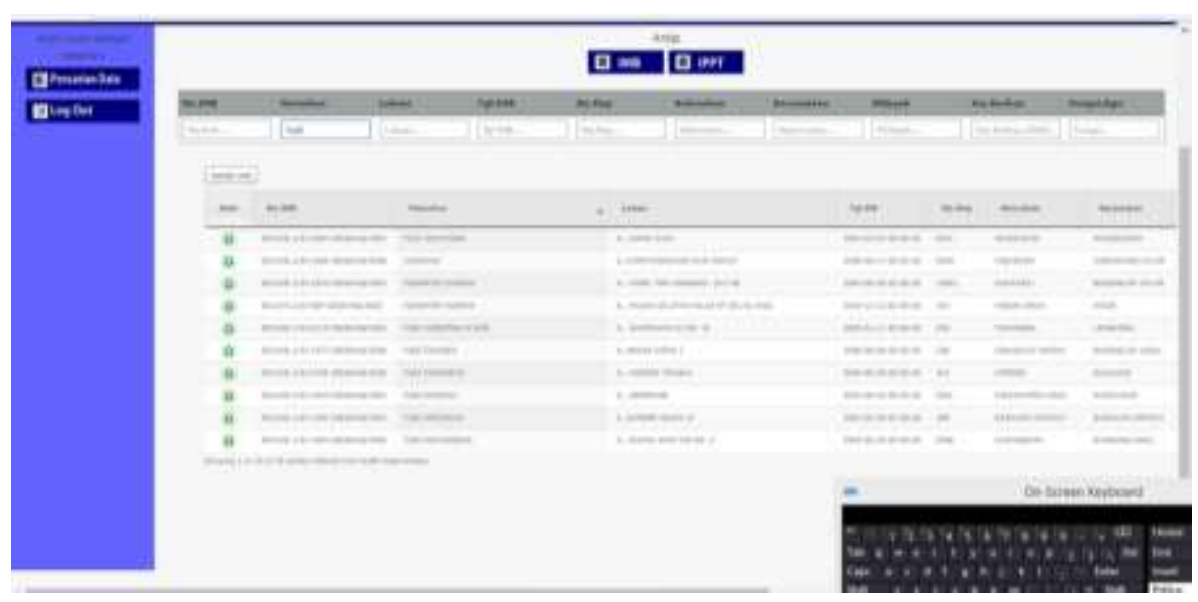

Gambar 9. Tampilan hasil input data 
4. Pencarian berdasarkan wilayah

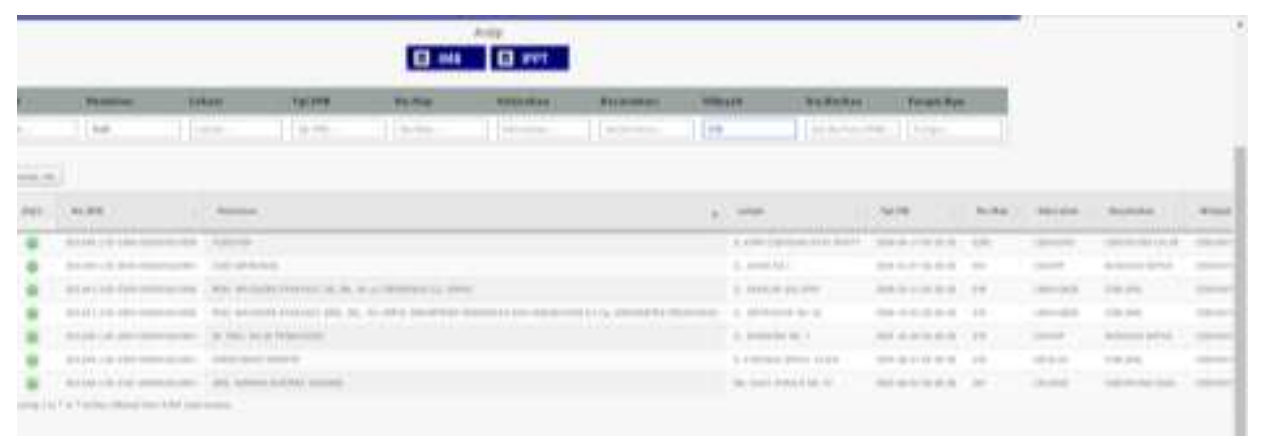

Gambar 10. Pencarian berdasarkan wilayah

5. Pencarian berdasarkan interval waktu

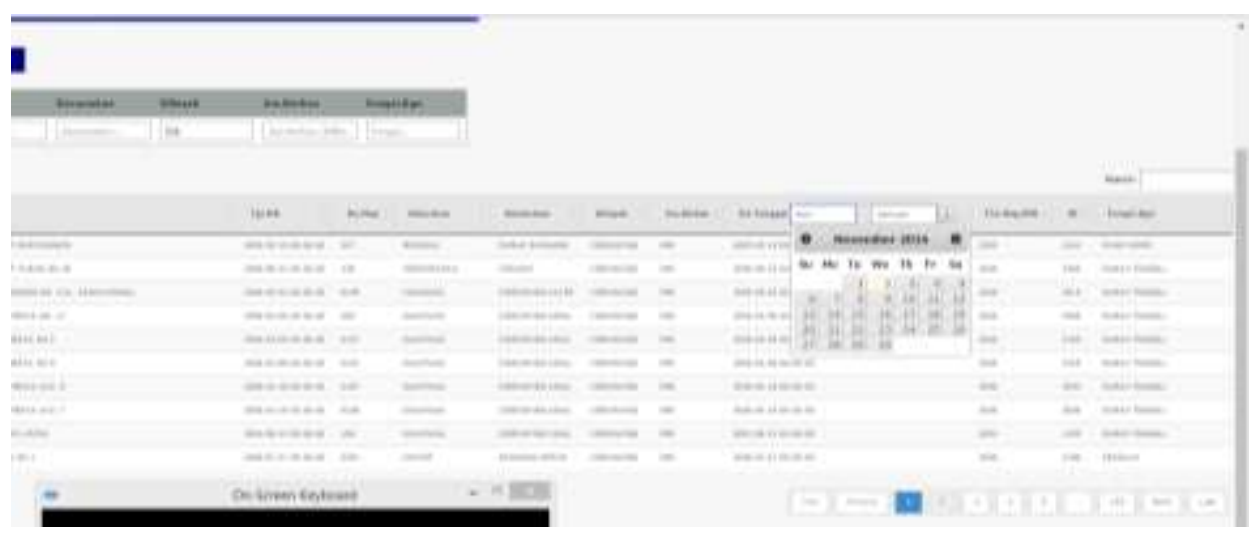

Gambar 11. Pencarian berdasarkan interval waktu

6. Tampilan view data untuk user Admin

Untuk melihat file arsip, dapat meng-klik icon pdf pada tampilan berikut ini

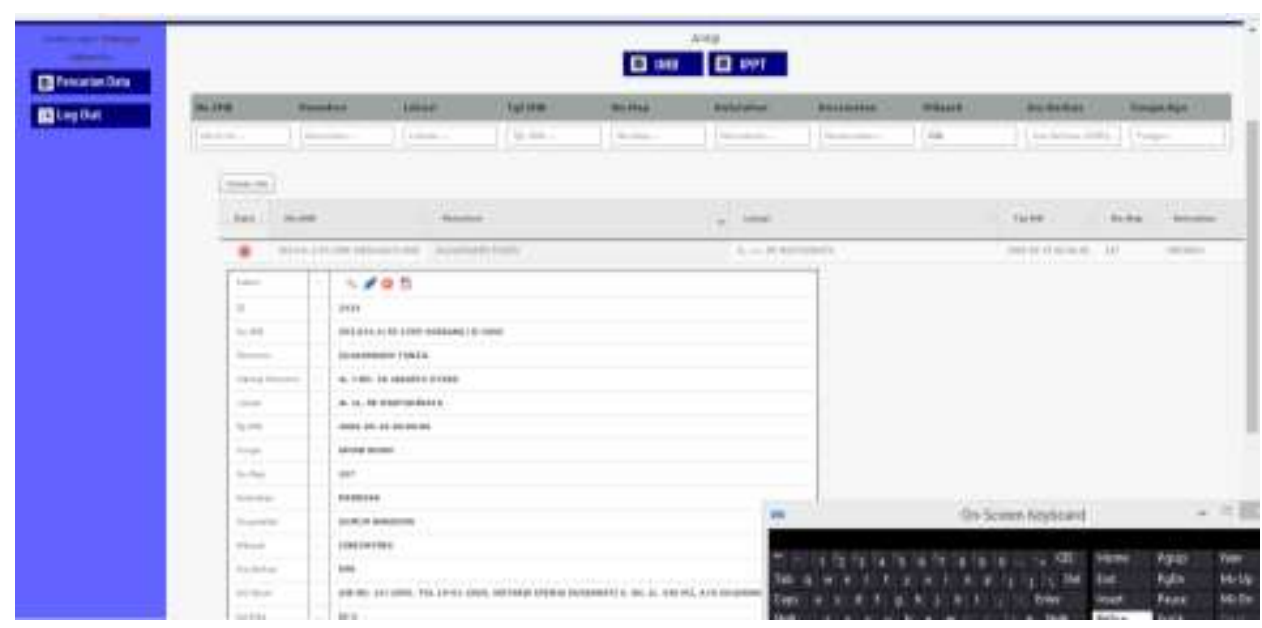

Gambar 12. Tampilan view data untuk user Admin 
7. Tampilan view detail data untuk user Staf

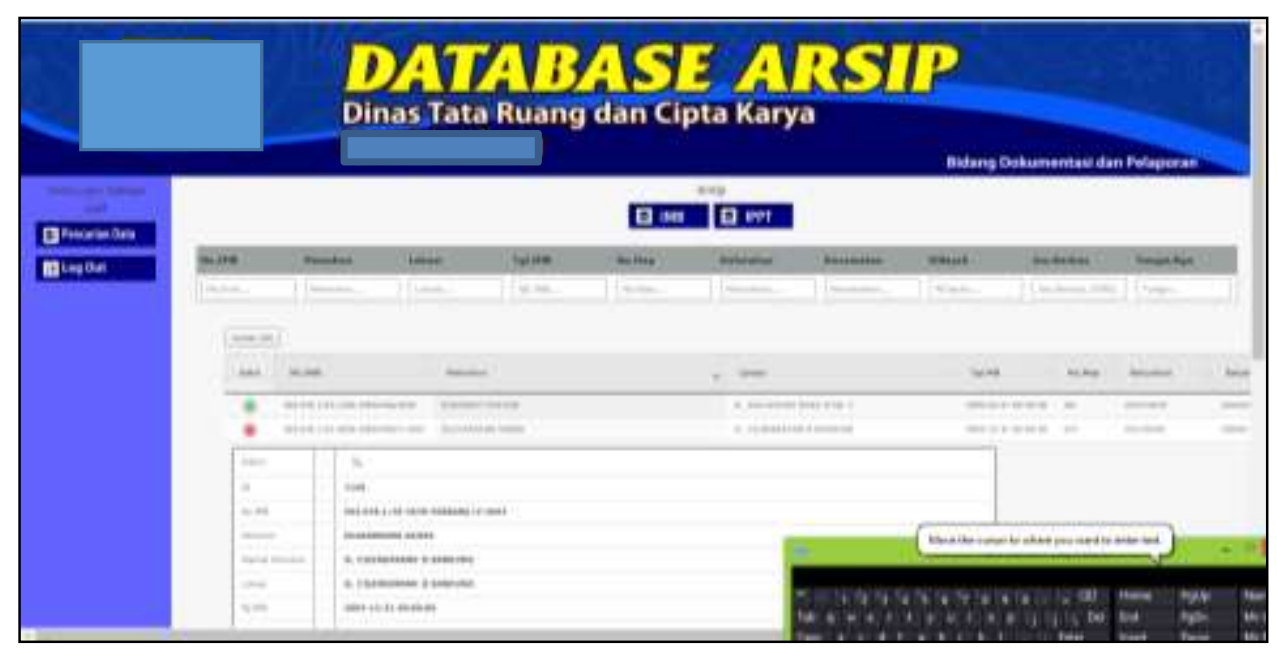

Gambar 13. Tampilan view data untuk user Staf

8. Hasil Scan dan Rekam dokumen IMB, IPPT dan dokumen kelengkapan lainnya. Dokumen IMB, IPPT dan dokumen lainnya di scan dan di rekam kedalam bentuk file PDF, untuk hasil dari digitalisasi dokumen-dokumen tersebut dapat dilihat pada gambar berikut ini :

\section{Dokumen IMB}

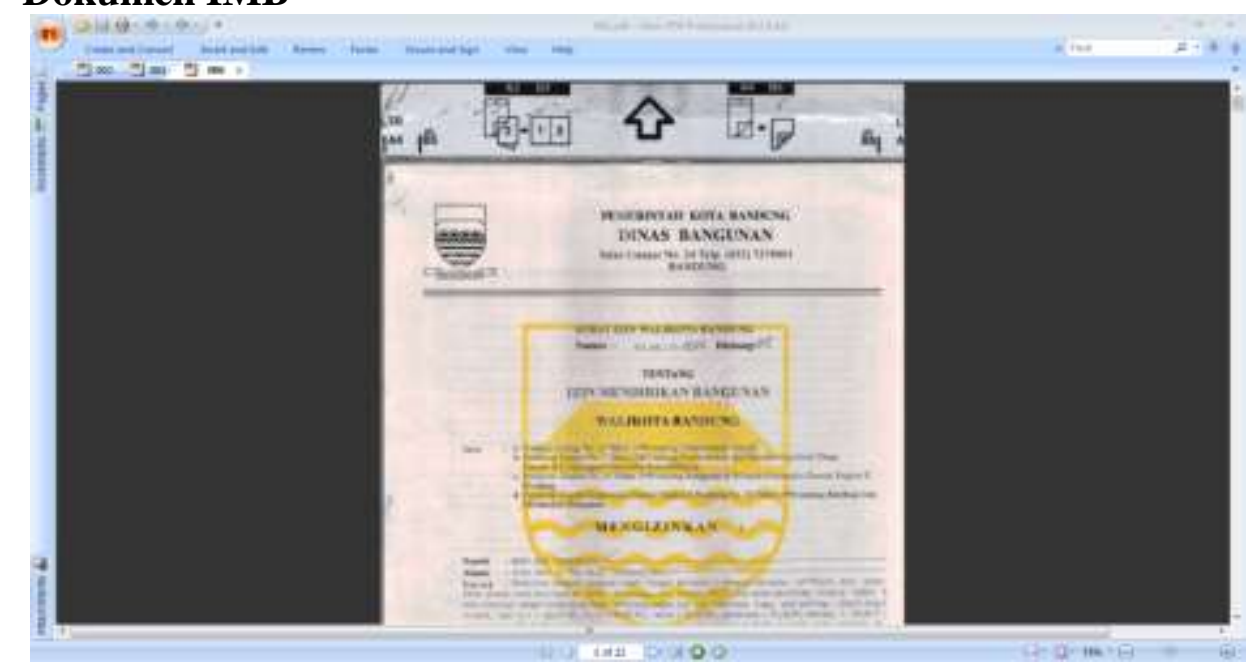

Gambar 14. Tampilan digitalisasi dokumen IMB 


\section{Dokumen IPPT}

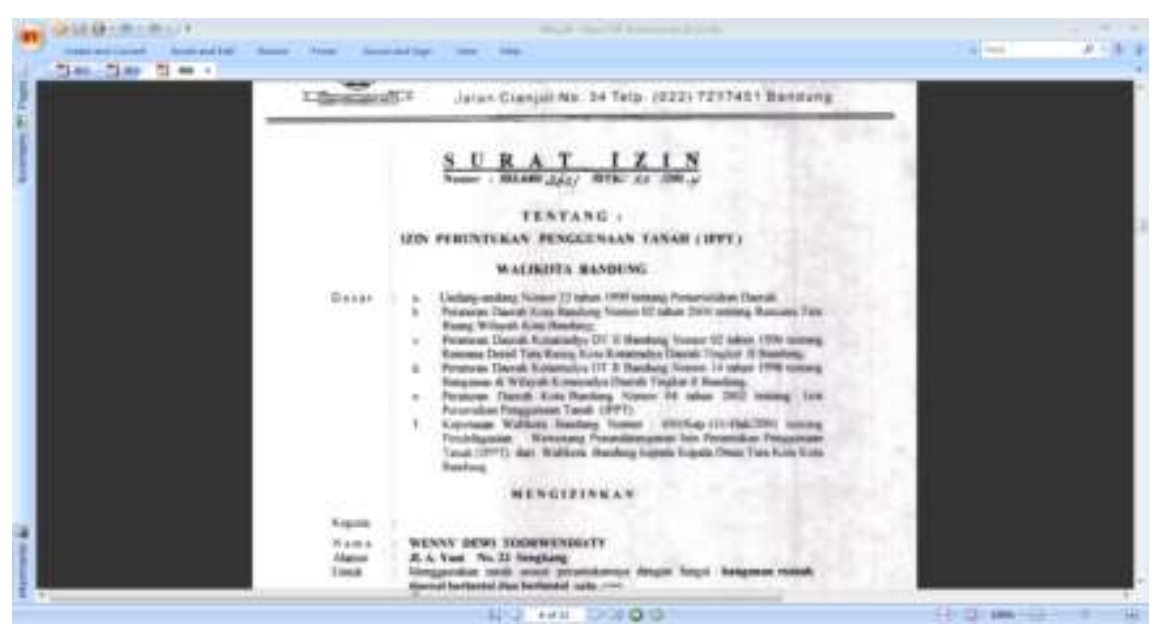

Gambar 15. Tampilan digitalisasi dokumen IPPT

Dokumen kelengkapan lainnya (buku tanah)

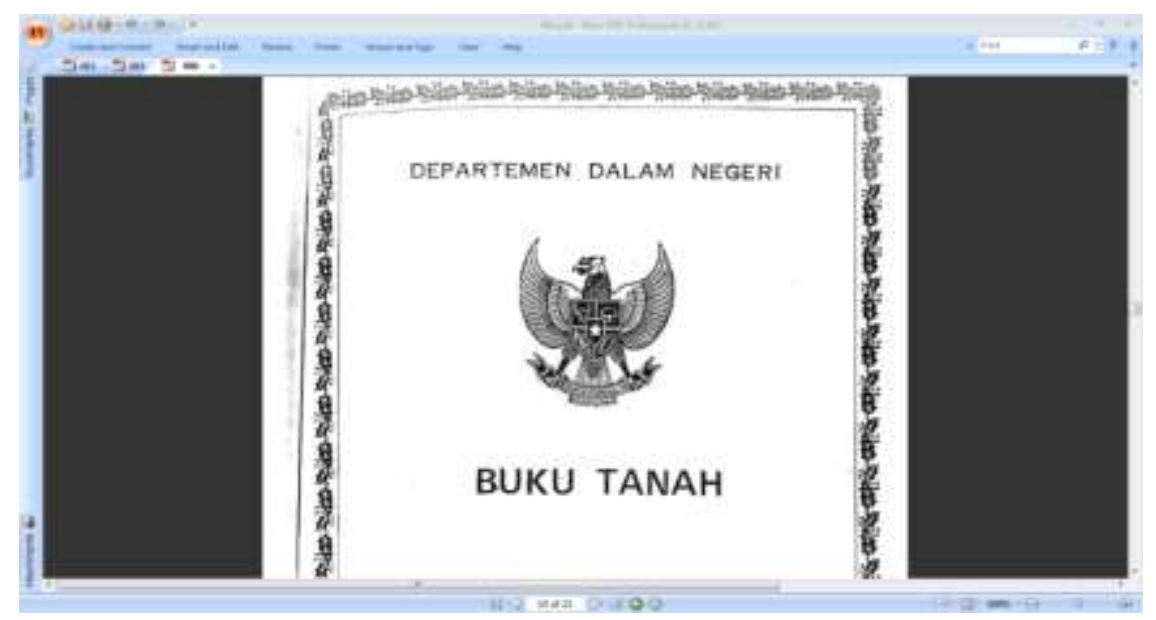

Gambar 16. Tampilan digitalisasi dokumen buku tanah

Dokumen kelengkapan (izin dari lingkungan/tetangga)

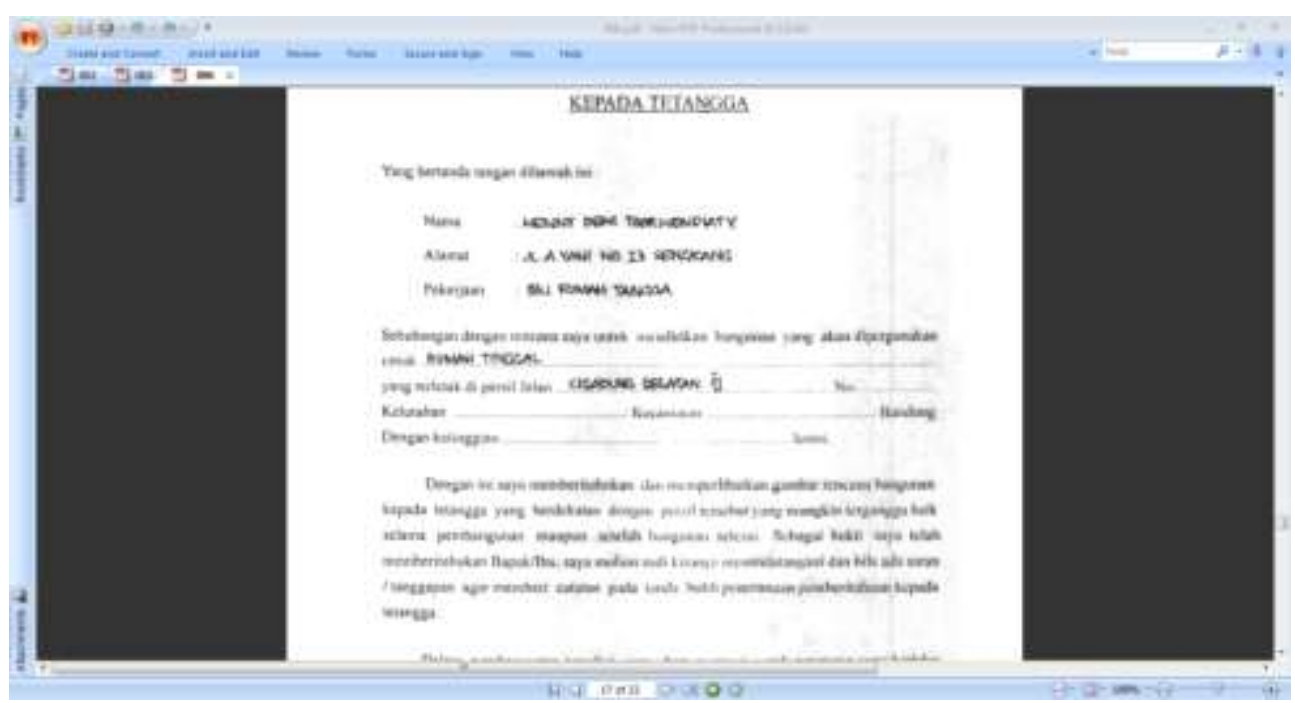

Gambar 17. Tampilan digitalisasi dokumen ijin lingkungan/tetangga 


\section{Dokumen kelengkapan lainnya (rencana kontruksi)}

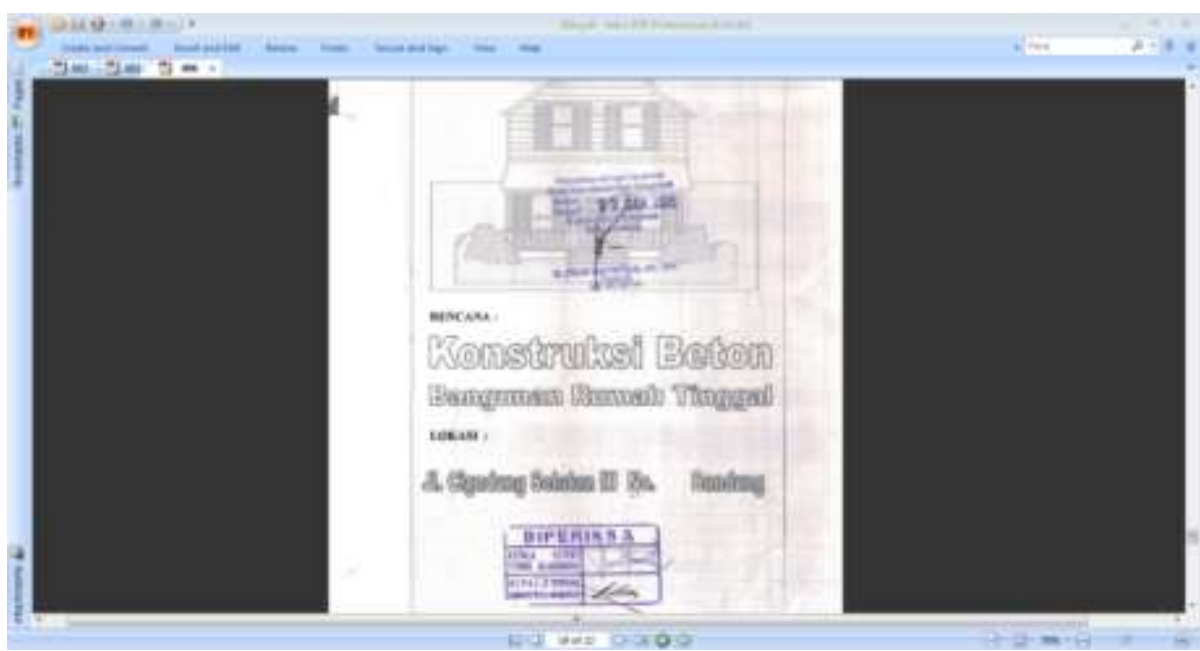

Gambar 18. Tampilan digitalisasi dokumen rencana konstruksi

\subsection{Jadwal Pelaksanaan Pekerjaan pada Entri Database Arsip IMB dan IPPT}

Berikut adalah jadwal pelaksanaan pekerjaan pada Entri Database Arsip IMB dan IPPT

\begin{tabular}{|c|c|c|c|c|c|c|c|c|c|c|c|c|c|c|c|c|c|c|c|c|c|c|c|}
\hline \multirow{3}{*}{ No } & \multirow{3}{*}{\multicolumn{2}{|c|}{ Uraian }} & \multicolumn{21}{|c|}{ Wititu Pelatsanasin petarjakn } \\
\hline & & & \multicolumn{4}{|c|}{ Bulanke-1 } & \multicolumn{4}{|c|}{ Bulanke-2 } & \multicolumn{4}{|c|}{ Bulanke-3 } & \multicolumn{5}{|c|}{ Butanke-4 } & \multicolumn{4}{|c|}{ Bulanke-5 } \\
\hline & & & 1 & 2 & 3 & 4 & $\mathbf{1}$ & 2 & 3 & 4 & 1 & 2 & 3 & 4 & $\mathbf{1}$ & 2 & 3 & & & 1 & 2 & 3 & 4 \\
\hline \multirow[t]{6}{*}{$\mathbf{1}$} & AES & SIAPAN DAN ANN ISIS \& KPUUIUUN & & & & & & & & & & & & & & & & & & & & & \\
\hline & 21 & Madilisasi Persunel & & & & & & & & & & & & & & & & & & & & & \\
\hline & 1.2 & Pertudaran kerthali KaX & & & & & & & & & & & & & & & & & & & & & \\
\hline & $\mathbf{1 . 3}$ & Mernyoun metodolosi krgiatan & & & & & & & & & & & & & & & & & & & & & \\
\hline & 14 & Perryounan Lachal Kerja & & & & & & & & & & & & & & & & & & & & & \\
\hline & 2.5 & Menejidentifikasikan ketututun data primer, setonder den peralatin & & & & & & & & & & & & & & & & & & & & & \\
\hline \multirow[t]{3}{*}{2} & $\operatorname{sen}$ & VYP PNDA SEIEM & & & & & & & & & & & & & & & & & & & & & \\
\hline & 2.1 & Kajian Arsip din metonisme itses arsip & & & & & & & & & & & & & & & & & & & & & \\
\hline & 2.2 & Kajian infrastruktur $\Pi$ & & & & & & & & & & & & & & & & & & & & & \\
\hline \multirow[t]{3}{*}{3} & ANA & UISA SESIEM DATARASE NESIP & & & & & & & & & & & & & & & & & & & & & \\
\hline & $\mathbf{3 . 1}$ & Analisis sistem equikasi dutahase berthasik wotb & & & & & & & & & & & & & & & & & & & & & \\
\hline & 3.2 & Analisis terthadap etssisting data & & & & & & & & & & & & & & & & & & & & & \\
\hline \multirow[t]{3}{*}{4} & ANA & UISA SSIIEM PERANGKATLUNAK DAN PEEANGKAT KEPUS & & & & & & & & & & & & & & & & & & & & & \\
\hline & 4.1 & Analisis Perranekat kerrs, OS dian jaringian infrastruter & & & & & & & & & & & & & & & & & & & & & \\
\hline & 4.2 & Analisis intograsi peranglet honik & & & & & & & & & & & & & & & & & & & & & \\
\hline \multirow[t]{5}{*}{5} & ENIE & $\begin{array}{l}\text { RI DATA IPPT DAN MEB EESERIA KEAENGKADAN TEENIS DAN } \\
\text { IINISTRASI RELINAN LAINNYA }\end{array}$ & & & & & & & & & & & & & & & & & & & & & \\
\hline & 5.1 & 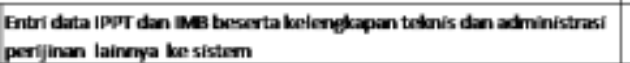 & & & & & & & & & & & & & & & & & & & & & \\
\hline & 5.2 & 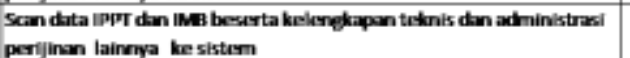 & & & & & & & & & & & & & & & & & & & & & \\
\hline & 5.3 & 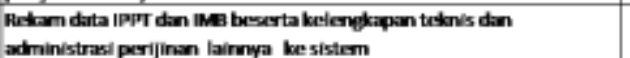 & & & & & & & & & & & & & & & & & & & & & \\
\hline & 54 & 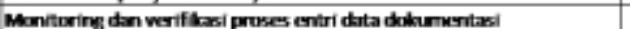 & & & & & & & & & & & & & & & & & & & & & \\
\hline \multirow[t]{3}{*}{6} & FINA & MISASI PEKERIAAN & & & & & & & & & & & & & & & & & & & & & \\
\hline & a.1 & Final Acoeptanofe (User acouptance) & & & & & & & & & & & & & & & & & & & & & \\
\hline & 6.2 & Sosialisasi din pelatithan & & & & & & & & & & & & & & & & & & & & & \\
\hline
\end{tabular}

Gambar 19. Jadwal Pelaksanaan Pekerjaan

\section{Daftar Pustaka :}

[1] Undang-undang Republik Indonesia No. 7 Tahun 1971 tentang ketentuan-ketentuan pokok kearsipan sebagai pengganti Peraturan Presiden Nomor 19 tahun 1961 tentang pokok- pokok kearsipan nasional.Undang-undang No.23 Tahun 1997 tenetang Pengelolaan Lingkungan Hidup. 
[2] Undang - undang Republik Indonesia No. 8 Tahun 1999 tentang Dokumen Perusahaan.

[3] Undang - undang Republik Indonesia No. 14 tahun 2008 tentang Keterbukaan Informasi Publik.

[4] Undang - undang Republik Indonesia Nomor 43 Tahun 2009 tentang Kearsipan.

[5] Undang-undang Nomor 23 Tahun 2014 tentang Pemerintahan Daerah.

[6] Keputusan Presiden Nomor 105 Tahun 2005 Tentang Pengelolaan Arsip Statis. 